\title{
Utmaningen från Beckford ${ }^{1}$
}

\author{
- en fokusgruppsstudie av religion i Storkøbenhamn
}

INA ROSEN

ENGLISH ABSTRACT: James Beckford claims that social scientific research in the field of religion can benefit from research into the everyday conceptualizations of religion in order to foster improved understanding of the object. This article presents Beckford's position, which lies at the foundations of a focus group based research project on ordinary Copenhagenites' conceptualizations of religion and belief.

DANSK RESUME: James Beckford påstår, at den samfundsvidenskabeligt orienterede forskning i religion kan drage nytte af forskning $i$ den hverdagslige forståelse af religion for at få et skarpere blik på sit objekt. I denne artikel præsenteres Beckfords position, som har dannet udgangspunkt for et fokusgruppebaseret forskningsprojekt om almindelige københavneres forståelse af religion og tro.

KEYWORDS: Social constructionism, religion, research, methodology, belief, Denmark

James Beckford fastslår att "social scientists do not need to make any assumptions about what religion is" och vidare att vi har behov för att

\footnotetext{
align religion as an object of social scientific analysis with its usage in everyday social life and in institutional settings. The raw material that social scientists have to analyse consists mainly of social interactions, reported experiences, structures and practices for which religious meanings have been claimed or contested. Any claims about the distinctiveness of religious phenomena will therefore have to be based on evidence that is not just an effect of how religion is conceptualised or defined (Beckford 2003, 22).
}

1 Oversat til svensk af Lars Ahlin 
Det kan vara av värde för oss att överväga Beckfords påståenden. De reser nämligen fundamentala frågor om hur vi som religionssociologer föreställer oss vårt forskningsobjekt, hur vi bedriver forskning i förhållande till det, och vilka perspektiv vi applicerar på det.

Beckfords hävdande ligger som grund för den studie jag 2008 utförde som en del av min doktorandutbildning vid Lunds Universitet. Denna studie är ett försök att utforska vad som kan framkomma med avseende på förståelse av hur ett urval danskar i Storköpenhamn gör sig föreställningar om religion och tro, och hur detta kan bidra till den teoretiska diskussionen om religion, i vad som ofta uppfattas som ett av världens mest sekulariserade länder. Det följande kommer kortfattat att uppsummera och diskutera Beckfords hävdande. Några av studiens resultat kommer att presenteras och en möjlig tolkning av data kommer att diskuteras. Beckford hävdar att vi som sociologer inte är tvungna att arbeta utifrån några förutfattade meningar om vad religion är. Istället skall vi sträva efter att studera och analysera religion - termen religion skall här endast ses som samlingsbeteckning snarare än något med en bestämd betydelse - som termen kommer i användning i vardagslivet. Det är resultaten av sådan forskning som, enligt Beckford, borde ge oss möjlighet att uttala oss om vad religion är och vilka dess effekter är, snarare än några specifika akademiska förutfattade meningar om vad religion är sui generis.

Denna forskningsansats är tydligt socialkonstruktionistisk. Den tar sin utgångspunkt i att religion inte har någon essentiell kärna, utan att den snarare är anfäktad både över tid och rum. På grund av att termen är så omstridd framgår det tydligt att olika sociala aktörer i samhället har olika intressen och att de kommer bestrida varandras rätt att avgöra vad religion är, hur det utförs, av vem och av vilka skäl.

Medan diskussionen om vad religion är för något än en gång har blivit aktualiserad inom religionssociologin idag (Voyé 2004), uppfordrar Beckford oss till att lägga all debatt om vad religion är till sida och gå ut i världen och se hur människor i deras vardagsliv konstruerar och förhandlar sig fram vad de ser som religion.

Beckfords ansats är inte utan inneboende problem, framförallt kunskapsfilosofiska. Det är emellertid intressant just av detta skäl eftersom det framhäver många av de filosofiska, metodiska och teoretiska problem som vi möter inom vårt forskningsområde.

Dessutom finns det en risk med denna ansats att vi oavsiktligt kommer att reducera religion till individualistiska föreställningar. I avsikt att undvika denna fallgrop förmanar Beckford oss att hålla fokus på de sociala innebörderna, såväl som på de individuella. Religion är trots allt socialt konstruerat. Där finns många tillfälligheter som spelar in med avseende på hur sociala varelser konstruerar religion vid en bestämd tid och plats. Många av dessa går utöver individen, till exempel social olikhet, tillgång till utbildning osv. Sådana aspekter sätter ramarna för hur en social verklighet konstrueras och förhandlas bland sociala aktörer. Sociala aktörer skapar asymmetriska relationer då de förhandlar om innehållet av begreppet religion. Därför är det lika 
viktigt, för sociologisk forskning kring konstruktion av religion, att betona överlappningar och spänningar som sådana blir uppenbara vid forskning bland sociala aktörer (till exempel Gergen 2001). Detta betyder inte att religion inte är någon verklighet och endast konstruktion. Oavsett på vilket sätt religion blir socialt konstruerat och anfäktat, har den verkliga effekter på verkliga människor i det verkliga livet. Men det betyder inte att religion är något per se, at där finns en essentiell kärna. Det betyder att ett antal tillfälligheter resulterar i bestämda konstruktioner och att dessa på olika sätt har konsekvenser för individer, grupper och samhället i stort.

Beckford uppmanar oss att ta på allvar det faktum att det finns sociala och kulturella förhållanden som bidrar till att skapa idéer, erfarenheter, texter och intellektuella system som betraktas som hörande till religion. Han uppmanar oss också till att ta de förändringar allvarligt som sker över tid med hänsyn till hur begrepp skapas i vardagen.

\section{Några konsekvenser av Beckfords påståenden}

Flera viktiga konsekvenser följer av Beckfords påståenden och några av dem kommer att diskuteras här nedan.

Det tycks vara grundläggande att ha en förhållandevis klar idé om vad vårt forskningsobjekt är, var vi kan studera det, likaväl som hur vi kan studera det. Denna fasta grund försvinner när vi ifrågasätter vårt objekt som sådant. Man kan fråga sig, varför vi överhuvudtaget skall ifrågasätta vårt objekt? Till detta finns det både empiriska och teoretiska skäl.

Först med hänsyn till teori. De flesta definitioner eller konceptualiseringar av religion utgår från att religion är liktydigt med ett komplex av beteenden, trosföreställningar, normer, värderingar och kunskaper som på något sätt överlappar och refererar till varandra. Till exempel antas det att en religiös kristen i det minsta har några kristna trosföreställningar, utövar någon form för kristen praktik och tradition, delar vissa normer och värderingar med andra kristna, och i viss utsträckning vet något om kristendomen och så vidare. Det antas vidare att han/hon är enig i vad det innebär att vara kristen - i annat fall skulle han/hon inte vara kristen. Denna uppfattning av religion skulle kunna kallas "paketerad religion" eftersom det förväntas att ett antal religionsdimensioner finns i ett och samma paket. Medan systematisk teologi är ett försök att paketera religion, så indikerar forskning i kognition (Boyer 2008) såväl som i religion (Ahern 1987; Stringer 1996) att antagandet om att religion som ett paket inte är en beskrivning som står i överensstämmelse med de flesta sociala aktörers uppfattning, inte ens bland dem som uppfattar sig själva som troende.

För det andra, vilka empiriska skäl finns det för att ifrågasätta vad religion är. Detta blir förhållandevis klart när vi ser hur folk svarar på frågor om sin religion. Enkätundersökningar ger en värdefull inblick i den komplexa relation människor har till religion. European Value Surveys visar att det finns en tendens till att många danskar 
svarar att de tror på gud, men att gud inte spelar någon roll i deras liv, och att de inte deltar i religiösa aktiviteter, men att de är medlemmar av ett religiöst samfund. (EVS 1999). Sådana motsägelsefulla svar kan förklaras genom att hävda att danskarna är pluralistiska, individualistiska och att religion har blivit privatiserat och något diffust eller framförallt att det är ett kulturellt fenomen som inte är relaterat till sann religiositet (se t.ex. Andersen \& Riis 2002; Gundelach, Iversen \& Warburg 2008; Zuckerman 2008).

Men, vad kunde vi tänkas hitta om vi tog upp Beckfords utmaning och överlämnade till våra forskningsobjekt att själva bestämma vad religion betyder. I dagligt tal refererar termen religion till en rad fenomen, som alltid utvecklas och som det sällan är enighet om, inte ens bland dem som i teorin delar de aktuella trosföreställningarna. Vi som religionssociologer kan inte hävda att vi är dem som vet vad religion är. Eller mer precist, enligt Beckford ger det ingen mening för sociologer att hävda att religion är någonting. Det är däremot informativt att undersöka hur begreppet används och diskuteras i vardagslivet. Vilka maktrelationer finns i sådana relationer? Hur blir givna representationer förankrade i samhället, i grupper, hos enskilda människor? Hur använder man sina representationer personligen? Hur interagerar sådana representationer med det omgivande samhället? Hur svarar de till och hänger de samman med andra utvecklingar i samhället och så vidare.

\section{Operationalisering av Beckfords utmaning}

Om vi nu tar upp Beckfords utmaning så kvarstår dock frågan vad vi skall göra i termer av forskning då vi inte vet vad religion är. Ett sätt att få inblick i hur religion förstås och används är genom att tala med människor om det och undersöka de processer varigenom vissa saker blir 'religiösa' och vilka effekter detta har på individer, socialitet och samhälle. Denna ingångsvinkel är på intet sätt ny. Det har gjorts i otaliga kvalitativa studier. Om vi emellertid går bort från våra antaganden om vad religion är och vilka effekter den har är vi tvungna att ompröva var och hur en sådan forskning skall utföras. Vi kan inte längre använda de konventionella forskningslokaliteterna, där vi förväntar oss att hitta religion. Dessutom har vi ingen uppfattning om vilka dimensioner som kan framkomma och som kan vara användbara för att förstå och kategorisera religion som den framkommer socialt. Vi är till stor del tillbaka på ruta ett.

Min studie från 2008 testar vad som kan dyka upp om man i görligaste mån sätter parantes om alla förutfattade meningar om religion. Enligt Beckford borde vi bland annat studera sociala interaktioner och rapporterade erfarenheter på vardagsnivå (Beckford 2003, 22). Min arbetshypotes var att fastän 3/4 av den danska befolkningen villigt betecknar sig själva som troende (European Value Surveys 1999) finns det liten enighet om vad detta innebär och därför är begreppet inte operationellt på de sätt som vi ofta använder det. Fokusgrupperna tänktes fungera som idé-generatorer med avse- 
ende på ämnen, och de skulle testa de frågor som uppstod som följd av hypotesen. Under våren 2008 gjorde jag 12 fokusgruppsintervjuer som fokuserade på två huvudsakliga ämnen som kunde belysa min arbetshypotes: (1) Vad betyder det att vara troende idag? och (2) Kan man vara mera eller mindre religiös? Fokusgrupperna kan uppfattas som platser där deltagarna gemensamt genom sin interaktion kunde konstruera mening om de aktuella ämnena genom att generellt indra sina livserfarenheter och specifikt de som hörde till de ämnen som diskuterades. Dessutom används fokusgrupper, sett från en metodologisk vinkel, ofta till att testa hypoteser och för idé-alstring (Fern 2001). Bägge användningsområden svarar till mina målsättningar.

I en konventionell religionsstudie skulle man högst sannolikt som fokusgrupper ha valt människor som kunde antas vara religiösa. Eller funnit dem i en miljö där något händer som påminner om religion. Beckford betonar emellertid att vi är tvungna att studera vardagslivet om vi skall kunna få en förståelse för religionens roll i samhället. Vardagslivet föregår för de flesta danskar på arbetet, i fritidsaktiviteter och hemma med familj och vänner. Religion har nödvändigtvis inte någon formell roll att spela i sådana miljöer. Mina fokusgrupper bestod därför av människor som inte var valda med utgångspunkt i att de hade någon form medlemskap i religiösa organisationer eller att de hade trosföreställningar av något speciellt slag. Tvärtemot, det enda deltagarna visste var att forskaren var intresserad i värderingar. De hade ingen förkunskap om de ämnen som skulle diskuteras.

Det finns naturligtvis andra sätt att nå fram till det samma. Där finns till exempel en underbar bok med titeln Heaven's Kitchen (Bender 2003). Hon beskriver här i detalj ett välgörenhetskök för terminalt sjuka AIDS-drabbade i USA. Då detta inte är en religiös organisation som sådan, för den samman människor med många olika bakgrunder, som alla av en eller annan anledning ägnar tid varje vecka till frivilligt arbete. När de talar om sin mission - att laga gourmetmat till döende människor - händer det också att de kommer att tala om religion. Detta sker framförallt när det blir tal om att gå i kyrkan, att göra förberedelser inför helger eller när de skojar om 'hellörade' (Bender 2003, 91). Dessa ämnen aktualiserades inte i avsikten att diskutera religion eller religiösa normer och värderingar som sådana, men kom upp när människor diskuterade sina vardagsaktiviteter och vardagsbestyr. Genom dessa samtal kom deras tolkningar och användningar av religion fram, inte som teologiska representationer men som en del av deras vardagsliv och vardagsdiskurs, antingen de var praktiserande religiösa eller inte.

En annan liknande studie är Abby Days tänkvärda intervjubaserade Believing in Belonging. Hon gick till ämnet med målsättningen att finna fram till vad vanliga människor tror på. Hon använder sig av en detaljerad explorativ intervjuguide och finner kort sagt fram till att medan där finns många sätt att tro så vad människor i grunden tror på är tillhörande (belonging) (Day 2006).

Genom diskussionerna i de 12 fokusgrupperna fann jag att människor aktivt skilde mellan olika konnotationer av ordet religion. Jag ger dessa konnotationer beteckningarna religion, tro, traditioner, praktik och religion-som-arv. Ytligt betraktat skiljer sig 
dessa resultat inte särskilt mycket från andra ansatser som tar utgångspunkt i att religion har flera olika aspekter som till exempel Glock (Kücükcan 2000). De aspekter jag fann i min studie hör emellertid inte till ett och samma idé-paket, exempelvis kristendomen. Ett typiskt exempel är från en grupp städare på en psykiatrisk institution i utkanten av Köpenhamn.

Kyrka och rosenkrans och sådana saker, det är religion för mig, men än en gång, det är inte fråga om att min tro kommer till uttryck, eftersom tro - jag tror på en massa saker. ... Jag har behållit dessa saker (bönbok etc.) så att när mina barn blir konfirmerade ... men det är mer, det är inte tro, det är tradition.

Distinktionerna mellan religion, tro och tradition är uppenbara.

Alla grupperna associerade faktisk religion med organisationen - kyrkan i de flesta tillfällen, eller synagogan vid ett enstaka tillfälle och Hindu-templet och prästen vid ett annat. Denna konnotation hör till religion i en rutiniserad form (Weber (1922) 1993). Trosföreställningar var inte nödvändigtvis något betecknande för religion. Tvärt emot tycks trosföreställningarna ha utvecklats genom individuella livserfarenheter och blivit aktualiserade ad-hoc och kontextuellt. De förstås av fokusgrupperna som personliga och privata. En ung manlig marknadsförare förklarade för de andra i sin fokusgrupp

... och det är svårt att förklara, faktiskt, precis som man inte kan förklara varför man älskar en annan människa, det är otroligt svårt. Du är tvungen att göra något tunt och bräckligt konkret och det är då det börjar falla sönder, i själva verket, om du skall förklara varför du älskar någon, visst dina ögon är fantastiska, det låter inte så fantastiskt som du faktiskt känner det, på ett eller annat sätt, därför att det är något mera, du vet, som du inte kan sätta ord på, varför du älskar en annan människa. Och det är sant för min tro, den är i mitt sinne, i min kropp, jag vet inte, det är svårt att uttrycka.

Trosföreställningar är inte systematiserade och de flesta deltagarna hade svårt att ge uttryck för dem. Deltagarna försökte hjälpa varandra genom att göra tillägg till varandras tankar eller genom att ge uttryck för olika föreställningar, vilket skapade en reflekterande och produktiv spänning.

Trosföreställningar tycks vara i hög grad personliga, men de är inte tillfälliga. Trosföreställningar faller in i ett antal kategorier som Högre makt, gud eller naturen. Men det är viktigt att förstå att trosföreställningar bara vid några få tillfällen refererar till rutiniserad religion. I alla andra fall har trosföreställningar överhuvud inte något att göra med rutiniserad religion. Det är således helt tydligt att det finns två skilda associationer - tro och rutiniserad religion - som kan vara oberoende av varandra. Fastän trosföreställningar i hög grad tycks vara personliga och individualistiska, följer det inte av detta att människor är inlåsta i solipsistiska trosföreställningar och att de inte delar erfarenheter som hör till den vardagliga förståelsen av religion. I mina data visade det sig också finnas andra aspekter av religion som delades av många. Medan 
trosföreställningar inte i någon väsentlig grad är relaterade till praktik så tillsluter sig alla deltagarna traditioner. Traditioner, trots att de ganska ofta har sin grund i rutiniserad religion, tycks vara helt blottade för religiöst innehåll. Traditioner är ett sätt att socialt bekräfta identiteten, gruppen, familjen och kulturen. Som sådana är de del av vad jag kallar religion-som-arv. Religion-som-arv är ett kulturellt uttryck, en delad bakgrund som stammar från en delad religiös historia, bestående av värderingar, idéer och normer. Uttalandet 'Jag är kulturkristen' var något som lika gärna en ateist som en troende kunde ställa sig bakom, men knappt någon av dem som sa det trodde på kristendomen. Vad de snarare tycktes säga var helt enkelt att de delade rötter med andra med samma kulturarv. En praktiserande buddhist med asiatiskt ursprung delade till exempel den kristna religion-som-arv. Hon förklarade att sådana normer har kommit att omvandlas till övergripande normer snarare än att vara religiöst specifika normer. På det sättet tycktes hon inte se någon motsättning mellan att ha en religionsom-arv som Buddhist å ena sidan och att vara medlem av en större kulturell kristen religion-som-arv å den andra.

Som nämnt tidigare finns det inom religionssociologin ett antal mer eller mindre detaljerade sätt på vilka det föreslagits att religion skulle utforskas som ett fenomen med många aspekter. Fishman skiljer till exempel mellan att veta, att göra och att vara, utan att det är tal om en nödvändig överlappning av de tre sätten att vara religiös på. Enligt denna distinktion kan en person ha stora kunskaper om sin religion utan att nödvändigtvis göra något religiöst (Fishman 1980). Glock, senare tillsammans med Stark, skiljde mellan erfarenhets-, tros-, ritual, kunskaps- och konsekvensdimension samt dimensionen för religiös praktik. Verbits modell är ett annat liknande exempel (Kücükcan 2000). Dessa, liksom andra försök att förklara religion, håller dock fast vid antagandet att religion är en överlappning av de aspekter som man identifierar. De antar att ritual, emotion, kunskap etc. hör till en och samma religion. De omvärderar därför inte heller tillräckligt att begreppet religion ses som ett paket. Modellerna är också huvudsakligen testade i omgivningar som är valda under antagandet att religion av något slag pågår där. Forskningslokaliteterna blir inte allvarligt ifrågasatta.

Från en kognitiv utgångspunkt är på liknade sätt uppfattningen av religion som ett paket tveksam. Religionsantropologen Pascal Boyer påpekar att

different cognitive systems handle representations of supernatural agents, of ritualized behaviours, of group commitment and so on, just as colour and shape are handled by different parts of the visual system. Most modern, organized religions present themselves as a package that integrates all these disparate elements (ritual, morality, metaphysics, social identity) into one consistent doctrine and practice. But this is pure advertising. These domains remain separated in human cognition (Boyer 2008).

Enligt detta perspektiv, oberoende av om religion av historiska, sociala eller kulturella tillfälligheter förstås som ett trossystem, organiserat i ett trossamfund eller inte, förstår inte hjärnan religion som ett paket. Den reagerar på olika stimuli genom olika 
nätverk och där finns inte något i den mänskliga hjärnan som medför att religion som ett paket blir övertygande eller överbevisande. Varje aspekt av religion, om den så är social, ritual, emotionell, erfarenhetsmässig, taktil, sensorisk, kognitiv eller av annat slag, hanteras av olika nätverk i hjärnan. Socialitet hanteras av andra nätverk i hjärnan än tro, än ritual.

\section{Ett sätt att förklara resultaten}

Min studie är ett försök att testa utfallet av en projektdesign som försöker sätta alla förutfattade meningar om vad religion är inom parantes. Det visar sig att mitt urval av respondenter förstår religion framförallt i termer av fem konnotationer av ordet, nämligen rutiniserad religion, tro, praktik, tradition och religion-som-arv. Dessa aspekter kommer dock inte fram varje gång och jag gör inte några universella hävdande med avseende på detta. Det centrala är att dessa aspekter kommer till synes i en forskning som ger företräde till vanliga människors sociala konstruktioner i vardagslivet. Vanliga människor, som deltagarna i de 12 fokusgrupperna, associerade dessa fem konnotationer med ordet religion. De hjälpte varandra att komma fram till innehållet i var och en av de fem aspekter. Ett innehåll som är något annorlunda i jämförelse med hur religion ofta förstås i det akademiska studiet av religion.

För att påminna om vad Beckford säger: "Social scientists do not need to make any assumptions about what religion is" och vidare att "any claims about the distinctiveness of religious phenomena will therefore have to be based on evidence that is not just an effect of how religion is conceptualised or defined in academia" (Beckford 2003, 22). Vilka hävdande kan då göras på grundval av mina resultat?

Grace Davie noterar att "the phrase 'privatized religion' is misleading to the extent that it overlooks the origins of our beliefs and the context in which they are held" (Davie 1994, 76). Termen religion kan emellertid hävdas vara missledande då den tvingar oss att anta att där med nödvändighet måste finnas en nära och överlappande relation mellan ett antal olika aspekter av religion.

Privatiseringen av religion som Davie nämner är faktiskt regelbundet beskriven som att den innefattar flera processer. En ligger i den ökande institutionella differentieringen genom vilken religion har förlorat sitt generella sociala inflytande och har dragit sig tillbaka till specialiserade institutioner. En samtidig process har varit det gradvisa etablerandet av en privat sfär i samhället, vilken i hög grad är skild från den offentliga. Människor går på arbete, till skola, de deltar i gemensamma aktiviteter och de går hem. Resultatet av detta är att hemmet blir skilt från rutiniserad religion. Det har inte längre någon social betydelse om man tillpassar sig religionen eller inte, framförallt inte inom den privata sfären i hemmet. Privatiseringsprocessen har gått ännu längre genom att individerna i ett givet hushåll inte självklart delar samma trosföreställningar, delar samma religiösa arv eller deltar i samma traditioner (Bruce \& Voas 2004). En och samma individ kan faktisk omfatta flera religiösa arv och njuta av reli- 
giösa traditioner som har sitt ursprung i mer än en religion-som-arv. Den privata sfären har på detta sätt blivit ännu mera tillbakadragen i förhållande till den offentliga, den har fått sin plats i det inre hos en person (Sointu 2005). Som konsekvens av dessa två processer har rutiniserad religion blivit en organisation bland andra i den offentliga sfären. Tron vilar tvärtemot solitt i individets inre.

Det växande avståndet mellan den offentliga sfären och den privata sfären påkallar uppmärksamhet till ett annat område. Detta kan kallas den sociala sfären. Det är där privata individer konstrueras genom sina möten med många skilda impulser från andra individer likaväl som från andra sociala aktörer som finns i det civila samhället, i offentliga institutioner eller i religiösa samfund.

Schematiskt talat blir den offentliga-privata dikotomin förstärkt genom den sociala sfären. Den sociala sfären träder fram när heterogena uttryck smälter samman i delade strukturer, meningar eller känslor. Detta kan ske i konversionen inom en fokusgrupp lika väl som i en frivillig politisk organisation, i en delad erfarenhet av musik eller konst, i det oförpliktigande samtalet eller genom konsumtion av förmedlade budskap.

\begin{tabular}{|l|l|l|}
\hline Offentlig sfär & Social sfär & Privat sfär \\
\hline $\begin{array}{l}\text { Marknaden för religiösa } \\
\text { samfund inkluderande } \\
\text { rutiniserade religion }\end{array}$ & Religioner-som-arv & Praditioner \\
& $\begin{array}{l}\text { Värderingar } \\
\text { Institutioner }\end{array}$ & \\
& Attityder & \\
\hline
\end{tabular}

De rutiniserade uttrycken för religion är lokaliserade i den offentliga sfären, vilken är skild från den private sfären i vilken vi finner trosföreställningar. Där är sällan några överlappningar mellan de privata trosföreställningarna och budskapen som har sitt ursprung i rutiniserad religion. Deltagarna i fokusgrupperna talar också om att antal aspekter av religion som de delar. De talar med kärlek om traditioner genom vilka familjerna kommer samman, om delade värderingar som genomsyrar samhället, om kyrkan som en delad symbolisk institution och de uttrycker delade attityder till hur religion på ett riktigt sätt skall uttryckas och erfaras. Dessa delade element inkluderar inte element som stammar från personliga trosföreställningar och fastän några av trosföreställningarna har sitt ursprung i rutiniserad religion så tycks banden däremellan i dag vara upplösta. De indikerar istället socialitet.

Religion som ett färdigt paket i vilket alla aspekter är sammanbuntade är helt tydligt på nedgång. Men vi behöver därför inte dra slutsatsen att människor blir sekulära, att de är irreligiösa, att de endast är kulturellt religiösa. Vi kan endast dra slutsatsen att detta speciella sätt att vara religiös på är på nedgång. Detta är en avgörande distinktion. Är vi tvungna att använda ordet religion för att beskriva tro, socialitet, religiöst arv, 
religiös praktik och tradition också när de inte är inkorporerade i en enhetlig organisation eller system? Religion förblir en nyttig etikett för alla dessa fenomen och många andra. Religion är precis som termerna kultur, familj, arbete, staden etc. - verksamma som meta-begrepp men de måste kontinuerligt ges ett aktuellt innehåll om de skall ha någon praktisk användelse.

\section{Avslutande anmärkningar}

Ifall jag fram till nu inte har varit tillräcklig klar så har mitt mål här inte varit att säga att alla konventionella lokaliteter, metoder och teoretiska ansatser har blivit föråldrade. Min avsikt har varit att betona att där finns några blinda fläckar i dessa konventionella ansatser och att vi behöver många andra slags studier som på något sätt försöker kompensera för dessa blinda fläckar. Vi har behov för studier som pekar på hur kategorin religion förändras och olika nya fenomen utvecklas - inte bara i sekteriska rörelser som new age eller nya religiösa rörelser som hela tiden drar till sig uppmärksamheten. Vi har behov för studier som siktar på den breda befolkningen för att kunna förstå varthän kategorin religion socialt är på väg. Eller som Beckford säger:

Given the wide extent of uncertainty and disagreement about what counts as religion in everyday life, it would be unwise for social scientists to intuit or to impose a definition of their own making, especially if it were restrictive. A better strategy is to map the varieties of meaning attributed to religion in social settings, to discern the relative frequency of the prevailing meanings and to monitor changes over time. ... This strategy also offers the advantage of maintaining a close connection between everyday uses of the term 'religion' and the identification of religion as an object of social scientific study (Beckford 2003, 20).

\section{LITTERATUR}

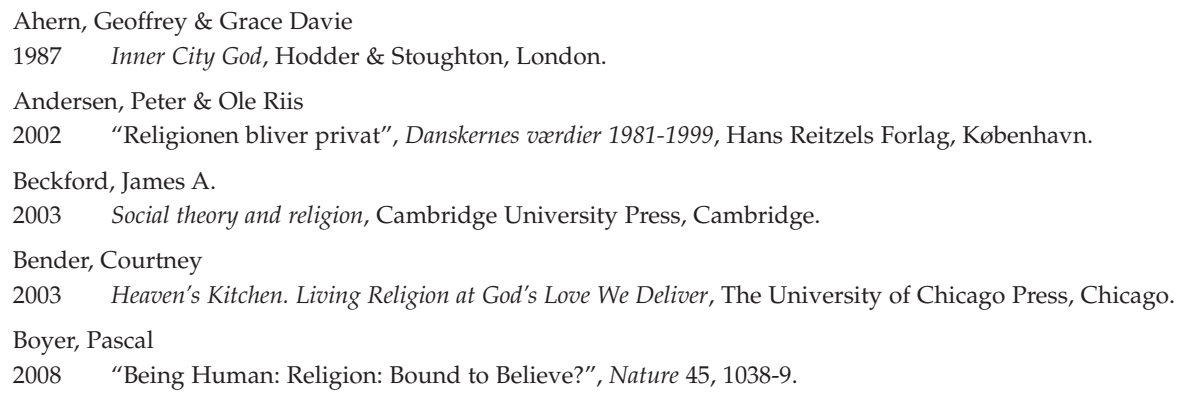


Bruce, Steve \& David Voas

2004 "The 2001 Census and Christian Identification in Britain", Journal of Contemporary Religion, Vol. 19, (1), 23-28.

Davie, Grace \& David Martin

1994 Religion in Britain Since 1945: Believing Without Belonging, Blackwell, Oxford.

Day, Abby

2006 Believing in Belonging in Contemporary Britain: a case study from Yorkshire, Lancaster University, Lancaster.

Fern, Edward

2001 Advanced Focus Group Research, Sage, London.

Gergen, Kenneth J.

2001 "A Civil World Beyond Individual and Community. Preliminary Draft for the symposium 'Civil Society between Liberalism and Communitarianism"”, Wien.

Gundelach, Peter, Hans Raun Iversen \& Margit Warburg

2008 I hjertet af Danmark, Hans Reitzel, København.

Sointu, Eeva

2005 "The Rise of an Ideal: Tracing Changing Discourses of Wellbeing", The Sociological Review 53 (2), 255 274.

Stringer, Martin

1996 "Towards a Situational Theory of Belief", Journal of the Anthropological Society of Oxford 27 (3), Michaelmas, 217-234

Voyé, Liliane

2004 "A Survey of Advances in the Sociology of Religion", New Approaches to the Study of Religion, Vol. 2: Textual, Comparative, Sociological, and Cognitive Approaches, Walter de Gruyter, Berlin, New York.

Weber, Max

1922 (1993) The Sociology of Religion, Beacon Press, Boston.

Zuckerman, Phil

2008 Society without God: What the Least Religious Nations Can Tell Us About Contentment, New York University Press, New York.

Ina Rosen, Ph.D.

Lund Universitet, Religionssociologi, Center for Teologi og Religiøse studier 